\title{
Effect of Simulated Browsing on Aspen Regeneration: Implications for Restoration
}

\author{
Bobette E. Jones, ${ }^{1}$ David F. Lile, ${ }^{2}$ and Kenneth W. Tate ${ }^{3}$
}

Authors are ${ }^{1}$ District Ecologist, United States Forest Service, Eagle Lake Ranger District, Lassen National Forest, Susanville, CA 96130, USA; ${ }^{2}$ Livestock and Natural Resources Advisor, University of California Cooperative Extension, Lassen County, Susanville, CA 96130, USA; and ${ }^{3}$ Rangeland Watershed Specialist, Dept of Plant Sciences, University of California, Davis, CA 95616, USA.

\begin{abstract}
Aspen (Populus tremuloides Michx.) is a disturbance-dependent, fire-resilient, shade-intolerant, clonal species that is in decline throughout western North America. The objective of this study was to examine the effects of intensity and season of browsing on annual height growth of aspen suckers. The goal was to aid development of livestock grazing strategies to restore stands in decline due to excessive livestock browsing. We implemented 33 combinations of intensity and season of browse on aspen suckers in three aspen stands on Eagle Lake Range District, Lassen National Forest, California, USA, during 2003 and 2004. Greatest growth was on suckers with no terminal leader browse and $\leq 25 \%$ of biomass removed from branches. Lowest growth occurred when $90 \%$ of terminal leader length and $50 \%$ of branch biomass was removed. Growth was most negatively affected by browse on terminal leader. Growth was lowest for suckers browsed midseason only and suckers browsed both early and midseason. Occurrence of conifer in the stand overstory significantly reduced sucker growth. Managers should minimize browse on terminal leaders, midseason browse over consecutive years, and repeated browse during a growing season.
\end{abstract}

\section{Resumen}

Alamo (Populus tremuloides Michx.) es una planta que depende del disturbio, es resistente al fuego, e intolerante a la sombra; clones de estas especies están desapareciendo a través de toda la parte oeste de Norte América. El objetivo de este estudio fue examinar los efectos de intensidad y temporada de ramoneo sobre el aumento anual de la altura de retoños de los álamos durante la época de crecimiento. El objetivo fue desarrollar estrategias de pastoreo para restaurar las poblaciones en disminución debido al excesivo ramoneo. Se realizaron 33 combinaciones de intensidad y época de ramoneo sobre los retoños de los álamos en tres poblaciones de álamos en Eagle Lake Range District, Lassen National Forest, CA, USA, durante los años 2003 y 2004. El mayor crecimiento se obtuvo en retoños en que no se ramoneó la hoja terminal y se removió $\leq 25 \%$ de la biomasa de las ramas. El menor crecimiento se presentó cuando el $90 \%$ de la longitud de la hoja terminal y el $50 \%$ de la biomasa de las ramas fue removido. El crecimiento fue negativamente afectado por el ramoneo en hojas terminales. El crecimiento de los retoños se afectó mas ligeramente cuando fueron ramoneadas sólo a la mitad de la temporada de crecimiento y los retoños ramoneados en al principio y a la mitad de la temporada. La ocurrencia de coníferas en la población en la parte superior redujo significativamente el crecimiento de los retoños. Los manejadores deben minimizar el ramoneo en hojas terminales, el ramoneo en la mitad de la temporada en años posteriores, y repetir el ramoneo durante una temporada de crecimiento.

Key Words: Cascades, frequency, grazing, intensity, Populus tremuloides Michx., season

\section{INTRODUCTION}

Aspen (Populus tremuloides Michx.) is a disturbance-dependent, fire-resilient, shade-intolerant, clonal species that relies on vegetative reproduction to maintain stands between episodic seeding events (Eriksson 1993; Romme et al. 1997; Shepperd et al. 2006). As Shepperd (2001) summarizes, successful aspen regeneration is dependent upon 1) release of apical dominance and subsequent hormonal stimulation of root buds to initiate suckering (Schier et al. 1985; Frey et al. 2003); 2) a growth environment that provides sunlight and warm soil temperatures (Doucet 1989; Fraser et al. 2002); and 3) protection of aspen suckers from excessive browsing (Bartos and Campbell 1998; Kay 2001; Rolf 2001).

Correspondence: Kenneth Tate, Dept of Plant Sciences, University of California, Mail Stop One, One Shields Ave, Davis, CA 95616, USA. Email: kwtate@ucdavis.edu

Manuscript received 16 June 2009; manuscript accepted 8 September 2009.
Aspen declines have been reported throughout western North America (Mueggler 1985; Bartos and Campbell 1998; White et al. 1998; Rogers 2002; Frey et al. 2004; Worrall et al. 2008). Bartos (2001) estimated a 50-96\% reduction of aspen acreage among seven states in the western United States compared to presettlement acreage. Di'Orio et al. (2005) found spatial extent of aspen in the Warner Mountains of northeastern California declined by $24 \%$ over a 48 -yr period. On Eagle Lake Ranger District, Lassen National Forest, $80 \%$ of aspen stands were found to be deteriorating because of shading by conifers and poor regeneration (Shepperd et al. 2006). However, other observers report areas of aspen persistence in the western United States (Kulakowski et al. 2004, 2006; Zier and Baker 2006; Binkley 2008; Sankey 2008). Kashian et al. (2007) assessed 91 northern Colorado Front Range aspen stands, found both declining and persisting stands, and concluded that stand decline was spatially and temporally heterogeneous across the landscape. 
Factors known to incite aspen decline include altered fire regime, excessive browsing by livestock and native ungulates, severe drought, disease, and insect damage (DeByle 1985; Mueggler 1985; Chong et al. 2001; Frey et al. 2004; Kaye et al. 2005; Kashian et al. 2007; Worrall et al. 2008). Lengthened fire return interval allows conifer succession in some aspen stands, creating a growth environment that cannot support aspen (Schier 1976; Bartos 2001; Kaye et al. 2005; Kashian et al. 2007). Early reports document loss of heavily grazed aspen stands and persistence of moderately grazed stands in the western United States (Baker 1918; Sampson 1919). Excessive browsing suppresses establishment of new aspen tree cohorts by maintaining suckers in a hedged growth form below the herbivore browse line, or total elimination of suckers (Bartos et al. 1994; White et al. 1998; Kay and Bartos 2000; Kay 2001; Turner et al. 2003; Dockrill et al. 2004). Studies have found heavy cattle grazing, particularly mid- to late growing season, to be an effective means to suppress aspen regeneration following conversion of aspen parkland to grassland (Fitzgerald et al. 1984; Bailey et al. 1990).

Aspen restoration in grazed landscapes is a priority for many resource managers (Jones et al. 2005; Shepperd et al. 2006; Bartos 2007). Excessive browsing by livestock, and some wildlife species, can be controlled with exclusionary fencing (Shepperd and Fairweather 1994; Kay and Bartos 2000; Kay 2001). However, widespread exclusionary fencing of aspen stands may not be ecologically or economically practical (Rolf 2001). The objective of this study was to examine the effects of intensity and season of browsing on annual height growth of aspen suckers. Aspen sucker recruitment, establishment of new stand cohorts, and stand restoration requires suckers to grow above the livestock and native ungulate browse line (about $1.5 \mathrm{~m}$ ). Understanding aspen sucker height growth response to intensity and season of browse is central to developing livestock grazing strategies to restore stands that are in decline due to excessive livestock browsing.

\section{METHODS}

\section{Study Area}

The study was conducted in northeastern California on Eagle Lake Ranger District (ELRD), Lassen National Forest. ELRD has cool moist winters and dry warm summers, with most precipitation occurring as rain and snow from November through May. The landscape has broad valleys and meadows that separate conifer forest-covered buttes dominated by Pinus ponderosa Laws. and Pinus jeffreyi Grev. \& Balf. below $1850 \mathrm{~m}$, and a mixture of Abies concolor (Gordon \& Glend) Lindley, Pinus lambertiana Douglas, P. ponderosa, P. jeffreyi, and Calocedrus decurrens Torrey above $1850 \mathrm{~m}$. Aspen stands cover approximately $1 \%$ of ELRD and are associated with meadow edges, rock outcrops, riparian areas, and forested areas with high water tables (aspen survey data, ELRD). Aspen are found from 1500 to $2200 \mathrm{~m}$ in elevation, on $0-45 \%$ slopes at all aspects, and on mollisol, inceptisol, and alfisol soils. Permitted cattle grazing occurs annually on ELRD from approximately 1 June through 30 September. Grazing allotments range from 4050 ha to 12140 ha in size and cattle numbers range from 150 to $800 \mathrm{cow}$-calf pairs per allotment.
An inventory of over 700 aspen stands on ELRD (Shepperd et al. 2006) was used to identify stands that were excluded from livestock grazing, had annual deer utilization on less than $5 \%$ of suckers, were not subject to elk browsing, were larger than $1.5 \mathrm{ha}$, and had over 1000 suckers $\cdot \mathrm{ha}^{-1}$ less than $1.5 \mathrm{~m}$ in height. Three stands from this pool were randomly selected for the study: Ashurst (2.8 ha, $1950 \mathrm{~m})$, Butte Creek (3.3 ha, $1706 \mathrm{~m}$ ), and Martin aspen stand (2.8 ha, $1731 \mathrm{~m})$. Over the two-year study period, annual precipitation on ELRD was $53 \mathrm{~cm}$ in 2003 and $38 \mathrm{~cm}$ in 2004, which was above average and average, respectively.

\section{Browsing Treatments}

Thirty-three simulated browsing treatments were implemented to represent gradients of browse intensity and seasonal timing observed across ELRD and northeastern California. Browsing treatments were randomly assigned to aspen suckers (experimental unit) and applied by hand pruning. Hand pruning standardized treatment application across suckers, stands, and years. Simulated browsing, however, does not duplicate all plant injuries associated with browsing or indirect grazing effects such as nutrient redistribution.

Treatments were a factorial combination of intensity and season of browse. Nine levels of browse intensity consisted of removing a percentage $(0 \%, 20 \%, 50 \%$, and $90 \%)$ of current year's growth length from an individual aspen sucker's terminal leader $(\mathrm{tl})$, and/or removing a percentage $(0 \%, 10 \%, 25 \%$, and $50 \%$ ) of the current year's growth biomass from a sucker's remaining branches (br). Season of browse treatment levels were early season only (first week of July), midseason only (first week of August), early and midseason, and late season only (first week of September). The same treatment was applied to each sucker in 2003 and 2004. Browsing treatments were replicated four times at Ashurst and Butte Creek and eight times at Martin based on abundance of aspen suckers in each stand. Two permanent line transects were established within each stand. Aspen suckers $<1.5 \mathrm{~m}$ tall and within $2 \mathrm{~m}$ of each line transect were tagged with a unique identification number and randomly assigned one treatment. There were two replicates of each treatment per transect at Ashurst and Butte Creek (66 suckers per transect), and four replicates of each treatment per transect at Martin (132 suckers per transect). Thus, 132 naturally growing aspen suckers at Ashurst and Butte Creek and 264 aspen suckers at Martin were treated for two years.

The height of the dominant stem (terminal leader) of each aspen sucker was measured at the end of the growing season in October 2002, 2003, and 2004. Height $(\mathrm{cm})$ measurements in October 2002 established initial heights for each sucker. Sucker heights in October 2002 were subtracted from heights in October 2003 to determine annual height growth for 2003 (year 1). Sucker heights in October 2003 were subtracted from heights in October 2004 to determine annual height growth for 2004 (year 2). Potentially important covariates were measured for each sucker and stand, including 1) sucker originated as a single stem or as one of multiple stems from the same root node, 2) sucker had a tree-like or hedged architecture, 3) sucker was deer browsed at any time during the study, and 4) stand had conifers present in the overstory or not (Table 1 ). 
Table 1. Summary of covariates measured in three study aspen stands on Eagle Lake Ranger District, Lassen National Forest, CA, USA, during 2003 and 2004. Conifer = conifer occurrence in stand overstory; Single $=$ percentage aspen suckers growing as a single sucker per root node; Multiple = percentage aspen suckers growing as multiple suckers per root node; Tree-like $=$ percentage aspen suckers with uninterrupted vertical growth; Hedged = percentage aspen suckers with shrub-like appearance due to repeated browse; Deer = percentage aspen suckers browsed by deer at least once during the study; Mortality = percentage aspen suckers that died during the course of the study.

\begin{tabular}{lccccccc}
\hline \multicolumn{1}{c}{ Stand } & Conifer & Single & Multiple & Tree-like & Hedged & Deer & Mortality \\
\hline Ashurst, $n=132$ & Yes & 50 & 50 & 84 & 16 & 4 & 8 \\
Butte, $n=132$ & No & 34 & 66 & 71 & 29 & 7 & 7 \\
Martin, $n=264$ & Yes & 48 & 52 & 93 & 7 & 12 & 5 \\
\hline
\end{tabular}

\section{Data Analysis}

Statistical analysis was first conducted to identify significant differences $(P \leq 0.05)$ in annual sucker height growth $(\mathrm{cm})$ among the 33 discrete browse treatments. A second factorial statistical analysis was conducted to investigate main and interacting effects of intensity and season of browse on annual sucker height growth. Linear mixed effects regression analysis was used for both analyses to address autocorrelation introduced by repeated measures on individual aspen suckers (Pinheiro and Bates 2000). Aspen sucker identity was used as a random group term to account for repeated measures in both analyses. For both analyses, annual sucker height data were transformed $\left[\log _{10}\right.$ (annual sucker height growth+1)] to normalize residuals, and an exponential variance function was used to create homogeneity of variance as determined via evaluation of standard diagnostic graphs (Pinheiro and Bates 2000).

To examine annual sucker height growth differences among the 33 browse treatments, initial fixed independent variables were browse treatment (33 levels), year (2003, 2004), stand (Ashurst, Butte Creek, Martin), conifer occurrence in stand overstory (yes, no), sucker architecture (tree-like, hedged), deer browse on sucker (yes, no), initial sucker height $(\mathrm{cm})$, number of suckers per root node (single, multiple), treatment by year interaction, treatment by stand interaction, and stand by year interaction. A final significant model was determined in a backwards stepping approach. A conditional $t$-test pairwise comparison of all browse treatments was used to determine which treatments were significantly different $(P \leq 0.05$; Pinheiro and Bates 2000).

For the factorial analysis of main and interacting browse treatment effects on annual sucker height growth, a backward stepping approach was employed to identify a final linear mixed effects regression model reflecting relationships between annual sucker height growth: browse treatment factors; twoway interactions between treatment factors, stand, and year; and covariates. Nonbrowsed control suckers were excluded from this analysis to allow for examination of interactions between browse factors. Initial fixed independent variables introduced during analysis were intensity of browse on terminal leader (tl); intensity of browse on branches (br); season of browse (early, mid-, early and mid-, late); year (2003, 2004); stand (Ashurst, Butte Creek, Martin); conifer occurrence in the stand overstory (yes, no); sucker architecture (tree-like, hedged); deer browse on sucker (yes, no); initial sucker height $(\mathrm{cm})$; number of suckers per root node (one, multiple); and two-way interactions between browse treatment factors, year, and stand. A conditional $t$ test was used to determine which fixed effects were significantly correlated with aspen sucker height growth, and regression coefficients were estimated using restricted maximum likelihood (Pinheiro and Bates 2000).

\section{RESULTS}

\section{Differences Between Browsing Treatments}

Pairwise comparisons of all treatments and ranking of these treatments from highest to lowest annual sucker height growth are reported in Table 2. There were significant differences $(P \leq 0.05)$ in annual height growth among the 33 browsing treatments. Occurrence of conifer was a significant predictor $(P<0.001)$ of annual sucker height growth, with less growth in stands with conifers. Year, stand, sucker architecture, deer browse on sucker, initial sucker height, number of suckers per root node, and all two-way interactions were not significantly correlated to annual sucker height growth $(P>0.1$ in all cases).

Six treatments that included browse on branches had apparently, not significantly, greater annual sucker height growth than nonbrowsed control treatment suckers (Table 2). Greatest annual height growth was observed on suckers with no terminal leader browse and no more than $25 \%$ of biomass removed from branches regardless of season. Suckers with lowest height growth had $90 \%$ of terminal leader removed and $50 \%$ of biomass removed from branches regardless of season. The remaining treatments were intermediate, and among these treatments less growth occurred when browse was early and midseason or midseason only compared to early season only or late season only.

\section{Browse Treatment Factor Analysis}

Annual sucker height growth was significantly affected by browse intensity and season, interactions of these factors, and the occurrence of conifer in the stand (Table 3). Season of browse, intensity of browse on terminal leader, intensity of browse on branches, quadratic form of intensity of browse on terminal leader, intensity of browse on terminal leader by season of browse interaction, and intensity of browse on terminal leader by intensity of browse on branches interaction were significant predictors of annual aspen sucker height growth $(P \leq 0.05)$. Annual sucker height growth decreased as intensity of browse on terminal leader increased, but magnitude of decrease depended on season of browse (Fig. 1). Intensity of browse on terminal leader also interacted with intensity of browse on nonterminal leader branches to determine annual sucker height growth (Figs. 2 and 3). Presence of conifers in aspen stands reduced annual sucker height growth regardless of intensity or season of browse (Table 3). Year, stand, sucker architecture, deer browse, initial sucker height, number of suckers per root node, and all two-way interactions were not significant ( $P>0.1$ in all cases).

\section{DISCUSSION}

Aspen sucker height growth response to browsing treatments ranged from +19 to $-88 \%$ of nonbrowsed control suckers 
Table 2. Mean annual aspen sucker growth $(\mathrm{cm})$ response to 33 browsing treatments applied to suckers in three aspen stands on Eagle Lake Ranger District, Lassen National Forest, California, USA, during 2003 and 2004. Each browse treatment was a combination of season of browse $\quad$ (early $=$ first week of July, mid- $=$ first week of August, late = first week of September), percentage of current year's growth length removed from terminal leader, and percentage of current year's growth biomass removed from branches.

\begin{tabular}{|c|c|c|c|c|}
\hline \multirow[b]{2}{*}{$\begin{array}{c}\text { Mean } \\
\text { separation }^{1}\end{array}$} & \multicolumn{3}{|c|}{ Browse treatment } & \multirow[b]{2}{*}{$\begin{array}{l}\text { Height growth } \\
(\mathrm{cm})^{2}\end{array}$} \\
\hline & $\begin{array}{l}\text { Season of } \\
\text { browse }\end{array}$ & $\begin{array}{c}\% \text { terminal } \\
\text { leader removed }\end{array}$ & $\begin{array}{l}\% \text { branches } \\
\text { removed }\end{array}$ & \\
\hline A & Late & 0 & 10 & 32.2 \\
\hline$A$ & Late & 0 & 25 & 30.9 \\
\hline$A B$ & Mid- & 0 & 25 & 29.4 \\
\hline$A B$ & Early and mid- & 0 & 25 & 26.8 \\
\hline$A B C$ & Mid- & 0 & 10 & 29.7 \\
\hline$A B C$ & Early & 0 & 25 & 28.0 \\
\hline$A B C D$ & Control-none & Control-none & Control-none & 27.0 \\
\hline$A B C D$ & Early & 50 & 0 & 23.1 \\
\hline BCDE & Early & 0 & 10 & 22.7 \\
\hline $\mathrm{BCDE}$ & Mid- & 20 & 0 & 22.0 \\
\hline BCDEF & Late & 20 & 10 & 22.9 \\
\hline BCDEFG & Late & 20 & 0 & 22.0 \\
\hline BCDEFG & Early and mid- & 20 & 0 & 21.4 \\
\hline BCDEFG & Early and mid- & 0 & 10 & 19.8 \\
\hline CDEFGH & Early & 50 & 25 & 19.1 \\
\hline DEFGHI & Mid- & 20 & 10 & 18.0 \\
\hline DEFGHI & Early & 20 & 0 & 16.7 \\
\hline DEFGHI & Late & 50 & 25 & 16.6 \\
\hline DEFGHI & Late & 50 & 0 & 16.4 \\
\hline DEFGHIJ & Early and mid- & 20 & 10 & 15.5 \\
\hline EFGHIJK & Late & 90 & 0 & 14.9 \\
\hline EFGHIJK & Early and mid- & 90 & 0 & 14.6 \\
\hline FGHIJK & Early & 90 & 0 & 16.1 \\
\hline GHIJK & Early & 20 & 10 & 12.4 \\
\hline HIJK & Mid- & 50 & 25 & 12.2 \\
\hline HIJK & Mid- & 50 & 0 & 10.9 \\
\hline IJK & Early and mid- & 50 & 0 & 12.4 \\
\hline IJK & Mid & 90 & 0 & 11.1 \\
\hline IJK & Early and mid- & 50 & 25 & 9.1 \\
\hline JKL & Late & 90 & 50 & 7.8 \\
\hline $\mathrm{KL}$ & Early & 90 & 50 & 8.2 \\
\hline $\mathrm{L}$ & Early and mid- & 90 & 50 & 4.0 \\
\hline $\mathrm{L}$ & Mid- & 90 & 50 & 3.1 \\
\hline
\end{tabular}

${ }^{1}$ Browse treatments with the same letter are not significantly different from one another $(P \geq 0.05)$ based on conditional $t$-test pairwise comparison.

${ }^{2}$ Mean annual aspen sucker height growth for suckers receiving each treatment across all years and stands.

(Table 2). Results of this study agree with reports that both intensity and season of browse affect aspen regeneration (DeByle 1985; Kays and Canham 1991; Campa 1992; Dockrill et al. 2004). Intensity of browse on terminal leader was negatively correlated with annual sucker height growth (Tables 2 and 3; Figs. 1 and 2). Annual sucker height growth was more negatively affected by browse on terminal leader than browse on branches. Effect of intensity of browse on branches interacted with intensity of terminal leader browse (Table 3;
Table 3. Results of linear mixed effects regression analysis predicting the effect of intensity and season of browsing treatments and occurrence of conifers on $\log _{10}$ (annual growth of aspen suckers +1 ) in three aspen stands on Eagle Lake Ranger District, Lassen National Forest, California, USA, during 2003 and 2004. Season of browse treatments were early (first week of July), mid- (first week of August), early and mid-, and late (first week of September) growing season. Browse intensity was the percentage of current year's growth length removed from terminal leader, and percentage of current year's growth biomass removed from branches. Conifer occurrence was presence or absence of conifer in the aspen stand overstory.

\begin{tabular}{|c|c|c|}
\hline Model term & $\begin{array}{c}\text { Regression } \\
\text { coefficient }\end{array}$ & $P$-value \\
\hline Intercept & 0.059 & $<0.0001$ \\
\hline \multicolumn{3}{|l|}{ Conifers occurrence in aspen stand } \\
\hline Present & 0.000 & - \\
\hline Absent & 0.065 & $<0.0001$ \\
\hline \multicolumn{3}{|l|}{ Season of browse } \\
\hline Early & 0.00 & - \\
\hline Early and mid- & -0.00035 & 0.965 \\
\hline Mid- & 0.01 & 0.199 \\
\hline Late & 0.019 & 0.026 \\
\hline Browse intensity on terminal leader & -0.00068 & 0.004 \\
\hline Browse intensity on branches & 0.00059 & 0.054 \\
\hline$(\text { Browse intensity on } \mathrm{tl})^{2}$ & 0.0000057 & 0.007 \\
\hline \multicolumn{3}{|c|}{ Season of browse $\times$ browse intensity on terminal leader } \\
\hline Early $\times$ browse on terminal leader & 0.00 & - \\
\hline Early and mid $-\times$ browse on terminal leader & -0.00017 & 0.214 \\
\hline Mid- $\times$ terminal browse on leader & -0.00037 & 0.009 \\
\hline Late $\times$ browse on terminal leader & -0.00026 & 0.070 \\
\hline \multicolumn{3}{|l|}{ Browse intensity on terminal leader $\times$ browse } \\
\hline intensity on branches & -0.000013 & 0.001 \\
\hline
\end{tabular}

Figs. 2 and 3). Positive growth response to browse on branches was observed as long as terminal leader browse was $\leq 20 \%$ (Tables 2 and 3, Fig. 3). At 50\% browse on terminal leader there was no response of growth to increased browse on branches. At $90 \%$ terminal leader browse there was a reduction in growth with increased browse on branches (Fig. 3). Annual growth may have increased with browse on branches when terminal leader browse was low because of hormonal stimulation to elongate the remaining leader, and reduced competition among remaining buds for root carbohydrates (Maini 1966). Growth eventually decreased with increasing browse on both branches and terminal leader, most likely because of substantial reduction in photosynthetic area.

Season of browse interacted with intensity of terminal leader browse to determine annual sucker height growth (Table 3; Fig. 1). Overall, growth was lowest for suckers browsed midseason only and early and midseason. There was little difference in growth for suckers browsed early season only, midseason only, and early and midseason when terminal leader browse was $20 \%$. However, as browse on terminal leader increased, early season only suckers outgrew midseason only and early and midseason browsed suckers (Fig. 1). Late season only browse suckers had greater growth compared to all other seasons of browse when terminal leader browse was $20 \%$ or $50 \%$. 


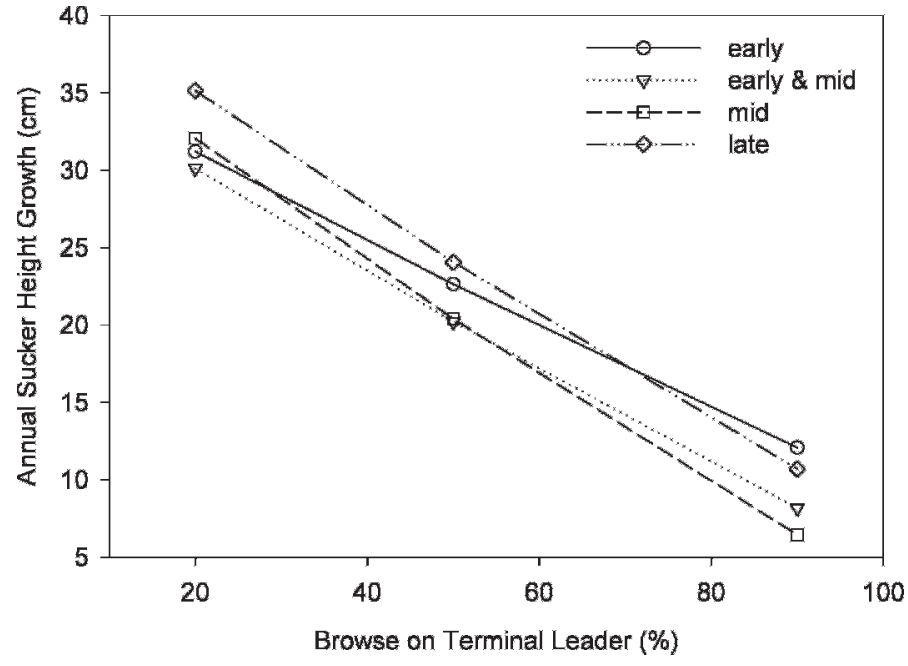

Figure 1. Product of linear mixed effects regression illustrating relationships between current year's growth length removed from aspen sucker terminal leader and annual sucker height growth $(\mathrm{cm})$ for suckers browsed early season only (1 July), midseason only (1 August), early and midseason, and late season only (1 September). Current year's growth biomass removed from sucker branches and conifer occurrence were set to zero and not present.

Season of browse affects amount of carbohydrates available to support sucker growth and duration of growing season remaining for regrowth after browse (Schier and Zasada 1973; Kays and Canham 1991; Dockrill et al. 2004). Our results agree with Fitzgerald et al. (1984) that intense browse in August (midseason) reduced aspen growth more than intense browse in June (early season). Kays and Canham (1991) found that browse after initiation of sucker growth in spring, but before cessation of above-ground growth in late summer, resulted in minimal sucker growth. This contrasts with

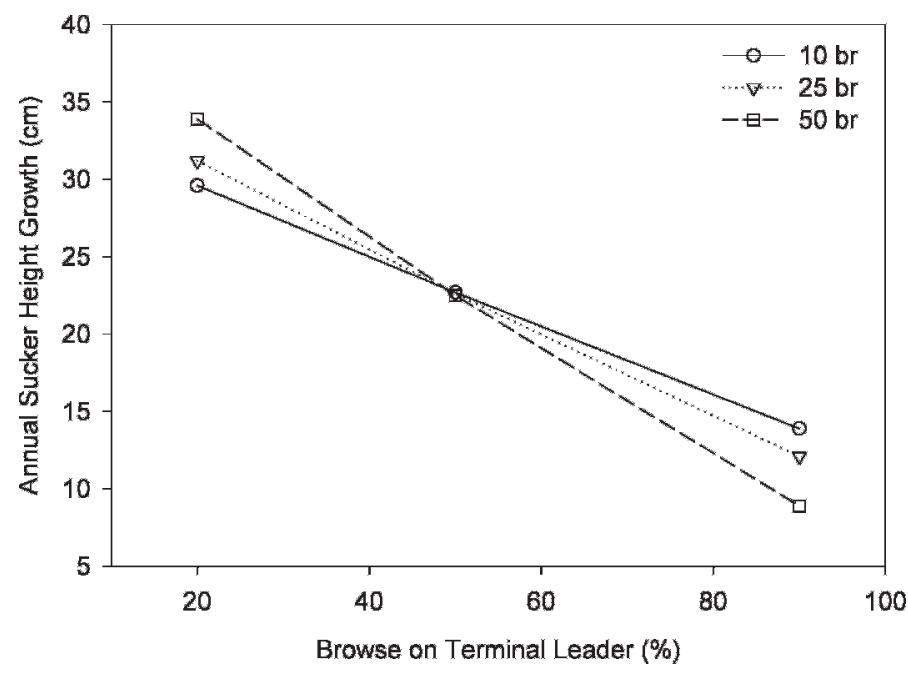

Figure 2. Product of linear mixed effects regression illustrating the interaction between percentage of current year's growth length removed from aspen sucker terminal leader, percentage of current year's growth biomass removed from sucker branches (br), and annual sucker height growth $(\mathrm{cm})$ for suckers browsed early season only (1 July) and without conifer present.

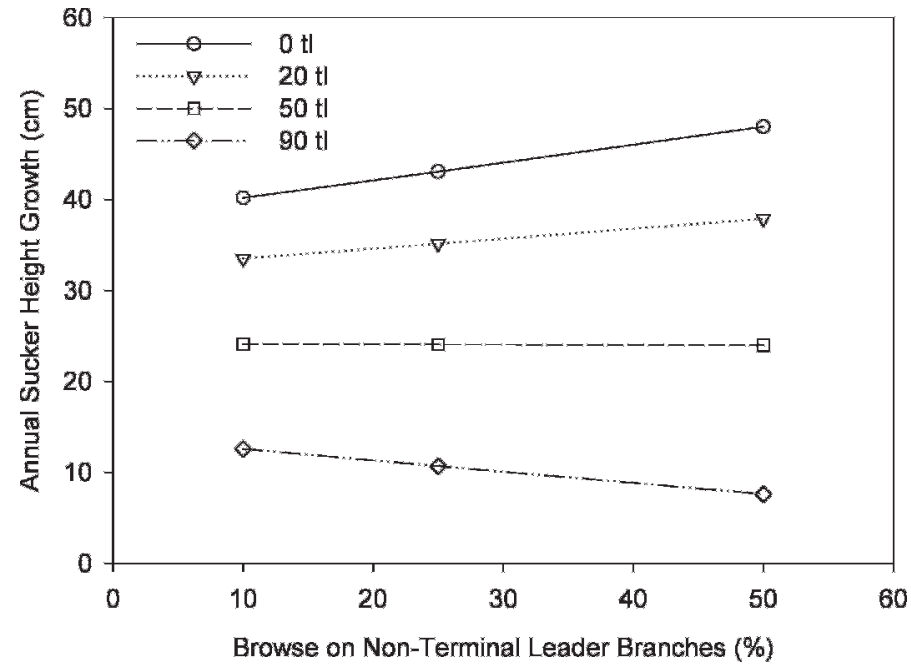

Figure 3. Product of linear mixed effects regression illustrating relationships between percentage of current year's growth biomass removed from aspen sucker branches and annual sucker height growth (cm) for suckers with $0 \%, 20 \%, 50 \%$, and $90 \%$ of current year's growth length removed from terminal leader (tl). Season of browse and conifer occurrence were set to early season only ( 1 July) and not present.

conventional theory that browsing just after leaf emergence, when carbohydrate reserves are lowest, would reduce sucker growth (Tew 1970; Schier and Zasada 1973). Early season only browse provides a relatively long regrowth period that may compensate for reduced carbohydrates. Suckers browsed late season had greater growth when terminal leader was browsed $\leq 20 \%$, likely because they were able to benefit from a full season of growth, photosynthesis, and translocation prior to browse. However, late season only browse suckers had less growth when terminal leader was browsed $>20 \%$, likely due to insufficient growing season remaining for regrowth. Controlling intensity of mid- and late season browse may be problematic because cattle tend to prefer aspen to other forages during the mid- and late season (Fitzgerald et al. 1986).

Suckers in stands without conifer had approximately $16 \mathrm{~cm}$ more annual height growth than suckers in stands with conifers in the overstory (Table 3). Shading from conifers creates lowlight intensities and reduces soil temperatures, which can diminish growth of aspen suckers (Farmer 1963; Gifford 1966; Shepperd 2001; Fraser et al. 2002; Frey et al. 2003). Reduced annual sucker growth due to shading by conifers can prolong the period that suckers are below the browse line and susceptible to height growth suppression by browsing.

\section{MANAGEMENT IMPLICATIONS}

Several factors are driving aspen declines across western North America. Where excessive livestock grazing is contributing to stand decline, protection of suckers from browse is a critical component of aspen restoration. Fencing stands can eliminate livestock browsing and is a good option for extremely degraded stands at risk of extinction. Across the broader landscape, managers can use grazing practices such as herding-watersupplement distribution activities, rest-rotation systems, and seasonal grazing strategies to actively manage the season, 
intensity, and frequency of browse on aspen suckers. Intensity of terminal leader browse is a major determinant of annual aspen height growth and should serve as a monitoring indicator for making livestock management decisions to enhance aspen regeneration. A key management goal should be to minimize browse on sucker terminal leaders. Suckers with $\leq 20 \%$ of terminal leader growth removed averaged over $50 \%$ of height growth observed on nonbrowsed control suckers and should grow above the browse line within several years. Midseason browse should be avoided over consecutive years. Intensity of terminal leader browse should be minimized during mid- and late season. Repeat browsing of suckers within a growing season should be avoided. Evidence of repeat browsing should be a signal to managers to adjust grazing management, primarily the amount of time livestock have access to a stand.

\section{ACKNOWLEDGMENTS}

We thank Gyna Ridenour, Shannon Cler, and Betsy Huang for their help with treatment implementation; Yukako Sado for data entry; Fred Kent for earlier discussions relating to aspen range management; Dale Bartos and Wayne Shepperd for sharing their expertise regarding aspen ecology and management; Tuyeni Mwampamba for reviews and comments on this manuscript; and Eagle Lake Ranger District, Lassen National Forest.

\section{LITERATURE CITED}

Balley, A. W., B. D. Irving, and R. D. FitzGerald. 1990. Regeneration of woody species following burning and grazing in aspen parkland. Journal of Range Management 43:212-215.

BAKER, F. S. 1918. Aspen reproduction in relation to management. Journal of Forestry 16:389-398.

Bartos, D. L. 2001. Landscape dynamics of aspen and conifer forest. In: W. D. Shepperd, D. Binkley, D. L. Bartos, T. J. Stohlgren, and L. G. Eskew [EDS.]. Symposium Proceedings: Sustaining aspen in western landscapes. RMRS-P-18. Grand Junction, C0, USA: US Department of Agriculture, Forest Service Rocky Mountain Research Station. p. 5-14.

Bartos, D. L. 2007. Aspen. In: S. M. Hood and M. Miller [eds.]. Fire ecology and management of the major ecosystems of southern Utah. RMRS-GTR-202. Fort Collins, CO, USA: US Department of Agriculture, Forest Service Rocky Mountain Research Station. p. 39-55.

Bartos, D. L., J. K. Brown, and G. D. Booth. 1994. Twelve years biomass response in aspen communities following fire. Journal of Range Management 47:79-83.

Bartos, D. L., and R. B. Campbell, JR. 1998. Decline of quaking aspen in the interior west: examples from Utah. Rangelands 20:17-24.

BINkLEy, D. 2008. Age distribution of aspen in Rocky Mountain National Park, USA. Forest Ecology and Management 255:797-802.

Campa, H., J. B. Haufler, and E. Byer. 1992. Effects of simulated browsing on aspen characteristics and nutritional qualities. Journal of Wildlife Management 65:158-164.

Chong, G. W., S. E. Simonson, T. J. Stohlgren, and M. A. Kalkahan. 2001. Biodiversity: aspen stands have the lead, but will nonnative species take over? In: W. D. Shepperd, D. Binkley, D. L. Bartos, T. J. Stohlgren, and L. G. Eskew [EDS.]. Symposium Proceedings: Sustaining aspen in western landscapes. RMRS-P-18. Grand Junction, CO, USA: US Department of Agriculture, Forest Service Rocky Mountain Research Station. p. 261-271.

DeByle, N. V. 1985. Management for esthetics and recreation, forage, water, and wildlife. In: N. V. DeByle and R. P. Winokur [EDs.]. Aspen: ecology and management in the western United States. GTR-RM-119. Fort Collins, CO, USA: US Department of Agriculture, Forest Service Rocky Mountain Forest and Range Experimental Station. p. 223-232.
Di'Orio, A. P., R. Callas, and R. J. Schaefer. 2005. Forty-eight year decline and fragmentation of aspen (Populus tremuloides) in the South Warner Mountains of California. Forest Ecology and Management 206:307-313.

Dockrill, C. W. M., P. I. V. Blenis, A. W. Bailey, and J. R. King. 2004. Effect of summer cattle grazing on aspen stem injury, mortality and growth. Forestry Chronicle 80:257-261.

Doucet, R. 1989. Regeneration silviculture of aspen. Forestry Chronicle 65:23-27.

ERIKsson, 0. 1993. Dynamics of genets in clonal plants. Trends in Ecology and Evolution 8:313-316.

Farmer, R. E. 1963. Effect of light intensity on growth of Populus tremuloides cuttings under two temperature regimes. Ecology 44:409-411.

Fitzgerald, R. D., R. J. Hudson, and A. W. Balley. 1984. Control of aspen regrowth by grazing with cattle. Journal of Range Management 37:156-158.

Fitzgerald, R. D., R. J. Hudson, and A. W. Balley. 1986. Grazing preferences of cattle in regenerating aspen forest. Journal of Range Management 39: 13-17.

Fraser, E. C., V. J. Lieffers, S. M. Landhausser, and B. R. Frey. 2002. Soil nutrition and temperature as drivers of root suckering in trembling aspen. Canadian Journal of Forest Research 32:1685-1691.

Frey, B. R., V. J. Lieffers, E. H. Hogg, and S. M. Landhausser. 2004. Predicting landscape patterns of aspen dieback: mechanisms and knowledge gaps. Canadian Journal of Forest Research 34:1379-1390.

Frey, B. R., V. J. Lieffers, S. M. Landhausser, P. G. Comeau, and K. G. Greenway. 2003. An analysis of sucker regeneration of trembling aspen. Canadian Journal of Forest Research 33:1169-1179.

GifFord, G. F. 1966. Aspen root studies on three sites in northern Utah. American Midland Naturalist 75:132-141.

Jones, B. E., T. H. Rickman, A. Vazquez, Y. Sado, and K. W. Tate. 2005. Removal of encroaching conifers to regenerate degraded aspen stands in the Sierra Nevada. Restoration Ecology 13:373-379.

Kashian, D. M., W. H. Romme, and C. M. Regan. 2007. Reconciling divergent interpretations of quaking aspen decline on the northern Colorado Front Range. Ecological Applications 17:1296-1311.

KaY, C. E. 2001. Long-term aspen exclosures in the Yellowstone ecosystem. In: W. D. Shepperd, D. Binkley, D. L. Bartos, T. J. Stohlgren, and L. G. Eskew [EDS.]. Symposium proceedings: sustaining aspen in western landscapes. RMRS-P-18. Grand Junction, CO, USA: US Department of Agriculture, Forest Service Rocky Mountain Research Station. p. 225-240.

KaY, C. E., AND D. L. BARTOS. 2000. Ungulate herbivory on Utah aspen: assessment of long-term exclosures. Journal of Range Management 52:145-154.

Kaye, M. W., D. Binkley, and T. J. Stohlgren. 2005. Effects of conifers and elk browsing on quaking aspen forest in the central Rocky Mountains, USA. Ecological Applications 15:1284-1295.

Kays, J. S., and C. D. Canham. 1991. Effects of time and frequency of cutting on hardwood root reserves and sprout growth. Forest Science 37:524-539.

Kulakowski, D., T. T. Veblen, and S. Drinkwater. 2004. The persistence of quaking aspen (Populus tremuloides) in the Grand Mesa Area, Colorado. Ecological Applications 14:1603-1614.

Kulakowski, D., T. T. Veblen, and B. P. Kunzel. 2006. Influences of infrequent fire, elevation and pre-fire vegetation on the persistence of quaking aspen (Populus tremuloides Michx.) in the Flat Tops area, Colorado, USA. Journal of Biogeography 33:1397-1413.

MainI, J. S. 1966. Apical growth of Populus spp. II. Relative growth potential of apical and lateral buds. Canadian Journal of Botany 44:1581-1590.

Mueggles, W. F. 1985. Forage. In: N. V. DeByle and R. P. Winokur [eds.]. Aspen: ecology and management in the western United States. GTR-RM-119. Fort Collins, CO, USA: US Department of Agriculture, Forest Service Rocky Mountain Forest and Range Experimental Station. p. 129-134.

Pinheiro, J. C., And D. M. Bates. 2000. Mixed effects models in S and S-Plus. New York, NY, USA: Springer. $528 \mathrm{p}$.

Rogers, P. 2002. Using forest health monitoring to assess aspen forest cover change in the southern Rockies ecoregion. Forest Ecology and Management 155:223-236.

RoLf, J. M. 2001. Aspen fencing in Northern Arizona: a 15 year perspective. In: W. D. Shepperd, D. Binkley, D. L. Bartos, T. J. Stohlgren, and L. G. Eskew 
[EDS.]. Symposium proceedings: sustaining aspen in western landscapes. RMRS-P-18. Grand Junction, C0, USA: US Department of Agriculture, Forest Service Rocky Mountain Research Station. p. 193-196.

Romme, W. H., M. G. Turner, R. H. Gardner, W. W. Hargrove, G. A. Tuskan, D. G. Despain, and R. A. Renkin. 1997. A rare episode of sexual reproduction in aspen (Populus tremuloides Michx.) following the 1988 Yellowstone fires. Natural Areas Journal 17:17-25.

Sampson, A. W. 1919. Effects of grazing upon aspen reproduction. US Department of Agriculture Bulletin Number 741. Washington, DC, USA: Government Printing Office. $29 \mathrm{p}$.

SANKEY, T. T. 2008. Learning from spatial variability: aspen persistence in the Centennial Valley, Montana. Forest Ecology and Management 255:1219-1225.

SCHIER, G. A. 1976. Physiological and environmental factors controlling vegetative regeneration of aspen. In: Symposium proceedings: utilization and marketing as tools for aspen management in the Rocky Mountains. RM-GTR-29. Fort Collins, CO, USA: US Department of Agriculture, Forest Service Rocky Mountain Research Station. p. 20-23.

Schier, G. A., J. R. Jones, And R. P. WinokUR. 1985. Vegetative regeneration. In: N. V. DeByle and R. P. Winokur [EDS.]. Aspen: ecology and management in the western United States. GTR-RM-119. Fort Collins, CO, USA: US Department of Agriculture, Forest Service Rocky Mountain Forest and Range Experimental Station. p. 29-34.

SchieR, G. A., AND J. C. ZaSADA. 1973. Role of carbohydrate reserves in the development of root suckers in Populus tremuloides. Canadian Journal of Forest Research 3:243-250.
ShePperd, W. D. 2001. Techniques to restore aspen forests in the western U.S. Transactions of the Western Section of the Wildlife Society 40:52-60.

Shepperd, W. D., and M. L. FalRweather. 1994. Impact of large ungulates in restoration of aspen communities in a southwestern ponderosa pine ecosystem. In: W. W. Covington and L. F. DeBano [EDS.]. Conference proceedings: sustainable ecological systems: implementing an ecological approach to land management. GTR-RM-247. Flagstaff, AZ, USA: US Department of Agriculture, Forest Service Rocky Mountain Forest and Range Experiment Station. p. 344-347.

Shepperd, W. D., P. C. Rogers, D. Burton, and D. L. Bartos. 2006. Ecology, biodiversity, management, and restoration of aspen in the Sierra Nevada. RMRS-GTR-178. Fort Collins, CO, USA: US Department of Agriculture, Forest Service Rocky Mountain Research Station. 122 p.

TEW, R. K. 1970. Root carbohydrate reserves in vegetative reproduction of aspen. Forest Science 16:318-320.

Turner, M. G., W. H. Romme, And D. B. Tinker. 2003. Surprises and lessons from the 1988 Yellowstone fires. Frontiers in Ecology and the Environment 1:351-358.

White, C. A., C. E. Olmsted, and E. E. Kay. 1998. Aspen, elk, and fire in Rocky Mountain National Parks of North America. Wildlife Society Bulletin 26:449-462.

Worrall, J. J., L. E. Egeland, T. Eager, R. A. Mask, E. W. Johnson, P. A. Kemp, and W. D. Shepperd. 2008. Rapid Mortality of Populus tremuloides in southwestern Colorado, USA. Forest Ecology and Management 255:686-696.

Zier, J. L., AND W. L. Baker. 2006. A century of vegetation change in the San Juan Mountains, Colorado: an analysis using repeat photography. Forest Ecology and Management 228:251-262. 